\title{
Comment to Pazos et al. (2019) "The oldest record of a tyreophoran track in Gondwana: Geological implications of subaerial exposure in the lower part of the Lajas Formation at the Covunco section (Neuquén Basin), Patagonia, Argentina"
}

\author{
Juan José Ponce ${ }^{\mathrm{a}, \mathrm{b}, *}$, Nerina Canale ${ }^{\mathrm{b}}$, Carlos Zavala ${ }^{\mathrm{c}, \mathrm{d}}$ \\ ${ }^{a}$ Consejo Nacional de Investigaciones Científicas y Técnicas, Instituto de Investigación en Paleobiología y Geología, Río Negro, Argentina \\ ${ }^{\mathrm{b}}$ Universidad Nacional de Río Negro, Instituto de Investigación en Paleobiología y Geología, Río Negro, Argentina \\ ${ }^{\mathrm{c}}$ Universidad Nacional del Sur, San Juan 670 (8000), Bahía Blanca, Argentina \\ ${ }^{\mathrm{d}}$ GCS Argentina SRL, Interna 1320 (8000), Bahía Blanca, Argentina
}

\section{Introduction}

The recent article published by Pazos et al. (2019) consists of a description of one tyreophoran track in deltaic deposits of the Middle Jurassic Lajas Formation, Neuquén basin, Argentina. In their sedimentological interpretation of the succession, the authors referred to several aspects of previous contributions (Zavala and González, 2001; Zavala, 2002; Canale et al., 2015), incurring in omissions and incorrect statements that we consider should be clarified, in order to avoid generating confusion in one of the classic Lajas Formation section in the Neuquén basin.

1- Pazos et al. (2019) made serious omissions about the origin and previous studies in the Lajas Formation mentioning that "A robust sedimentary facies model is based on the study of a series of outcrops belts situated onto or to the south of Huincul High (e.g. McIlroy et al., 2005; Rossi and Steel, 2016; Gugliotta et al., 2015a,b; 2016a,b; Kurcinka et al., 2018; Steel et al., 2018)."

Pazos et al. (2019) cannot ignore the excellent and detailed work performed by Yacimientos Petrolíferos Fiscales (YPF) during the eighties and nineties, summarized in Gulisano and Pando (1981), Gulisano et al. (1984), Legarreta and Gulisano (1989), and Gulisano and Gutiérrez Pleimling (1995). In particular, the first detailed facies characterization of deltaic deposits in Puesto Seguel area was performed by Gulisano and Hinterwimmer (1986). Zavala (1993) measured and analyzed in detail more than $6 \mathrm{~km}$ of stratigraphic sections located southward of the Huincul Arch, discussing facies, sequence stratigraphy and also the interaction between fluvial and tide-dominated deltas (Zavala, 1996a, b).

2- Pazos et al. (2019) mentioned “... while Canale et al. (2015a,b) for the locality studied in this paper suggested hyperpycnal fluvial discharges to the base (prodelta) and wave action to the top."
This is not correct. Canale et al. (2015a,b) interpreted the deposits of the Lajas Formation in the areas of Arroyo Covunco (AC) and Sierra de la Vaca Muerta (SVM) as accumulated in a fluvio-dominated deltaic system, frequently affected by hyperpycnal discharges and reworked by wave action. Hyperpycnites have been recognized not only within prodelta facies, but in all analyzed subenvironments. Hyperpycnal channels and lobes in AC and SVM were also documented by Zavala and González (2001) for the first time. Alternatively, Canale et al. (2015a,b) highlighted the fluvio-dominated character of the system over tide and wave influences, suggesting that hyperpycnal deposits were common all along the deltaic succession.

3- Pazos et al. (2019) also indicated, "Contrarily, in outcrops to the north of the Huincul High, in both Sierra de la Vaca Muerta and Covunco area (Fig. 1, area 1) there are only a few and less detailed studies ..."

Pazos et al. (2019) omitted the existence of highly detailed sedimentological and ichnological studies that determined for the first time the fluvio-dominated character of the deltaic deposits exposed in AC and SVM (Canale and Ponce, 2012; Ponce et al., 2012; Canale et al. 2015a,b, 2016). Curiously, the work of Canale et al. (2015a,b) is later recurrently discussed. In addition, the authors ignored a large number of contributions related to detailed palynological analyses, which provided significant paleoenvironmental information of the Lajas Formation in these localities (Volkheimer, 1970, 1978; Quattrocchio and Sarjeant, 1992; Martínez et al., 2001, 2016; Quattrocchio et al., 2001; Martínez and Quattrocchio, 2005).

4- Pazos et al. (2019) stated that their paper "... confirms the original idea of Zavala (2002) and invertebrate palaeontologists (see below) that the Covunco section is Bathonian-Callovian in age."

This is incorrect. Zavala (2002) never mentioned that age for the

DOI of original article: https://doi.org/10.1016/j.jsames.2019.05.014

* Corresponding author. Consejo Nacional de Investigaciones Científicas y Técnicas, Instituto de Investigación en Paleobiología y Geología, Río Negro, Argentina.

E-mail addresses: jponce@unrn.edu.ar (J.J. Ponce), ncanale@unrn.edu.ar (N. Canale), czavala@criba.edu.ar, czavala@gcsargentina.com (C. Zavala). 
Covunco section. An age range between Late Bajocian-Early Callovian was proposed by Zavala (2002), see also Zavala and González (2001), their Fig. 15 for the proposed age of sequences 1 to 5 .

5- In the last paragraph of the Introduction, Pazos et al. (2019) mentioned that "In the Covunco section, Canale et al. (2015a,b) interpreted the Lajas Formation as a continuous shallowing upward delta system (Canale et al., 2015a,b, Fig. 2). It is dominated by hyperpycnal fluvial discharges in the prodelta basal part, prograding over the marine pelites of the Los Molles Formation and continuing with fluvial dominated delta front deposits ending with wave-dominated distributary-bay deposits. According to Canale et al. (2015a,b), the unit is entirely deltaic and it is composed of about more than $500 \mathrm{~m}$ of continuous prograding deposits."

As mentioned above (see answer 1), hyperpycnites are present in all the deltaic sub-environments analyzed in AC and SVM (Canale et al., (2015a,b). The second assertion is also wrong, because interdistributary bay deposits have not been recognized in our contributions (AC and SVM sections of Canale et al. 2015a,b, 2016). Excellent examples of interdistributary bay deposits have been documented in the Lajas Formation outcrops exposed in the Bajada de Los Molles section (Gugliotta et al., 2015a; Canale et al., 2020).

6- In the same paragraph it is stated, “... a vertebrate track was documented less than $200 \mathrm{~m}$ above of the traditional basal contact of the unit. This discovery is the oldest tetrapod track record of the Neuquén Basin and confirms the subaerial exposure, but also cast doubt about the large prodelta interpretation suggested by Canale et al. (2015a,b)..."

Pazos et al. (2019) confirmed the presence of an interval that underwent subaerial exposure based on the recognition of an isolated and doubtful footprint. This assertion has two problems: 1- the presence of a footprint does not constitute evidence of subaerial exposure, and 2- a set of evidence that can link physical and biogenic sedimentary structures (desiccation cracks, soil development, rhizoliths, among others) are typically needed to interpret subaerial exposure (as well as a consistent paleoenvironmental framework of the underlying and overlying strata). The stratigraphically equivalent interval to that containing the doubtful footprint, located $700 \mathrm{~m}$ to the east-southeast, shows lenticular bodies eroding heterolithic deposits with a suite of trace fossils characteristic of marine environments (Gyrochorte, Chondrites, Planolites, Nereites, Asterosoma, Thalassinoides, Hilichnus) and the absence of physical and biogenic sedimentary structures diagnostic of subaerial exposure (Canale et al., 2013 a, Fig. 1 therein; Canale et al., 2015a,b). Furthermore, the heterolithic deposits above and below the supposed dinosaur footprint interval exhibit the same trace fossil association, indicating similar marine environments and rejecting the idea of continental deposition in a shallowing succession as suggested by Pazos et al. (2019).

\section{Geological setting}

7- Pazos et al. (2019) stated, “... the (Neuquén) basin reaches Chile, particularly in the north where it crops out in several regions in the border between Argentina and Chile."

This is not the Neuquén basin; this is the Andean geosyncline that extends up to Peru, partially sharing a similar stratigraphy with respect to that of the Neuquén basin.

8- Pazos et al. (2019) stated, “... the Huincul High is an E-W structural division that separates the basin in a North and a South part. This structure was active during the Jurassic but was completely inactive during the Cretaceous (Naipauer et al., 2012)."

This is incorrect, Naipauer et al. (2012) stated "Its genesis falls within the early history of the Huincul deformation zone, where several structural features indicate pulses of growth since Early Jurassic times prior to the main Andean contractional cycle started in the Late Cretaceous". Therefore, the Huincul arch was active during the Early
Cretaceous. This is supported also by field evidence. In the Cerro Lotena area, a well-documented (also fossiliferous) section of the Lower Cretaceous Agrio Formation (Suero, 1951) was recognized in between near-vertical strike-slip faults. This fault system is then passively sealed by red beds of the Upper Cretaceous Neuquén Group.

9- Pazos et al. (2019) indicated, "The object of this study is part of one of these units, lithostratigraphically known like Cuyo Group (Legarreta and Gulisano, 1989)."

The term Cuyo Group was not defined by Legarreta and Gulisano (1989), but by Dellapé et al. (1978). Legarreta and Gulisano (1989) used the Cuyo Subsystem, coined by Riccardi and Gulisano (1992).

10- Pazos et al. (2019) stated, "The marine Cuyo Group (Fig. 2) represents the first of these marine intervals and comprises three major units deposited during Pliensbachian-Callovian times that include offshore marine shales (Los Molles Formation), deltaic deposits starting in the Toarcian (Lajas Formation), and continental no deltaic-related fluvial deposits of post Late Bajocian age (Challacó Formation)."

This is incorrect. The Cuyo Group extends from Hettangian to Early Callovian (Riccardi et al., 1988). Additionally, is not clear the meaning of "continental no deltaic-related fluvial deposits" for the Challacó Formation. This unit was interpreted as the fluvial equivalent of deltaic deposits of the Lajas Formation (Gulisano et al., 1984) and more recently as lacustrine deposits with sublacustrine channels (Zavala and González, 2001).

11- Pazos et al. (2019) stated "In a 3rd order (millions of years) sequence stratigraphy framework, Los Molles Formation corresponds to the transgressive system tract, the Lajas Formation is part of the regressive system tract as well as the Challacó Formation, while the Tábanos Formation is the desiccation of the marine parts of the basin."

This is essentially incorrect. Third-order cycles span from 1 to 10 My, whereas the considered interval is about $35 \mathrm{Ma}$ (Hettangian-Early Callovian), and consequently falls within the range of second order (10-100 My) sequences. Additionally, considering the entire Los Molles Formation (often exceeding $1000 \mathrm{~m}$ thick) as part of a transgressive systems tract is an oversimplification. The reader is referred to the pioneering work of Gulisano et al. (1984) about sequence stratigraphy of the Jurassic stratigraphic section.

12- Pazos et al. (2019) stated that the Bathonian age "... contrasts with the record of bivalves (Cooper, 2015; Lambert, 1944; Leanza, 1987) and palynological studies (Martínez et al., 2002) that suggest a Callovian age at least for the middle and upper part of the succession."

Bivalves in the Neuquen basin cannot provide enough resolution to calibrate depositional sequences. The Bathonian age for the upper sequence was proposed by Gulisano (pers. comm.) according to the ammonoid fauna recovered by the YPF Geologic Commission 1. Additionally, Martínez et al. (2002) did not provide biostratigraphic markers, since it follows the stratigraphic scheme and ages indicated in Zavala and González (2001).

13- Pazos et al. (2019) mentioned "Interestingly, Zavala and González (2001, Fig. 15) suggested that the lower sequence prograded to the north, while the upper one exhibits a retrograding stacking pattern. This contrasts with the entirely continuous progradation interpreted by Canale et al. (2015a,b) for the entire succession in the area."

Seems that Pazos et al. (2019) never read the paper by Zavala and González (2001). The pattern shown in Fig. 15 for sequences 2 to 5 is associated to a northward tectonic migration of the depocenter, not retrogradation stacking pattern. Detailed sedimentological and ichnological studies in AC and SVM, show a marked progradational stacking pattern described by Zavala and González (2001, their p. 58), Canale et al. (2015a,b, 2016) and Ponce et al. (2015). We must recognize that the progradational pattern becomes more evident when both the AC and SVM sections are analyzed, yet this pattern is also documented in 
the AC section described by Pazos et al. (2019). On the other hand, Zavala and González (2001) recognized five depositional sequences (Seq.1 to Seq.5), indicating that their origin is related to synsedimentary tectonic activity, a situation that is not at all inconsistent with the presence and development of a continuous deltaic system. The ichnological dataset also supports a progradational pattern with prodelta and delta front facies, where an impoverished Cruziana ichnofacies is transitionally replaced by an impoverished Skolithos ichnofacies (Canale et al., 2015a,b, 2016; Ponce et al., 2015; Ponce and Carmona, 2016). Furthermore, the presence of Glossifungites ichnofacies (substrate-controlled ichnofacies) in surfaces interpreted as produced during avulsion stages of the deltaic system, constitute extremely frequent processes in depositional systems affected by allogeneic and authigenic controls (Riba, 1976; Bhattacharya, 2006). Similarly, the Lajas Formation in the Picún Leufú Anticline locality records synsedimentary tectonic activity with several progressive unconformities (Freije et al., 2002; Zavala and Freije, 2002; Naipauer et al., 2012), that generated a 560 m-thick deltaic succession (McIlroy et al., 2005; Ponce et al., 2012, 2015; Canale et al., 2015a,b, 2020, ; Rossi and Steel, 2016; Gugliotta et al., 2015a; Steel et al., 2018). The Glossifungites ichnofacies associated with autocyclic and allocyclic processes has also been recognized at this locality (McIlroy et al., 2005; McIlroy, 2007; Ponce et al., 2015; Canale et al., 2015a,b).

\section{Stratigraphy and sedimentology}

\subsection{Lower section}

14- Pazos et al. (2019) interpreted the lower section as “... a deltaic system prograding from the northeast to the southwest with paleocurrents variations related to tidal currents. Convolute stratification in medium to coarse-grained deposits, climbing and meter-scale cross stratified structures with internal normal grading are indicative of fluvial mouth bars prograding over a shallow marine system (Asteriacites) with tidal influence and rapid sedimentation documented by convolute stratification. It is similar to the fluvial dominance suggested by Gugliotta et al. (2016a,b). However, the heterolithic deposits and the sigmoidal structures with cyclical drapes suggest tidal modulation, and the cross-bedded sandstone units are completely tidally reworked and are not fluvial (contrast with Gugliotta et al., 2016a).”

Pazos et al. (2019) omitted a central aspect of the contribution made by Canale et al. (2015a,b) (see section 4.2. page 130), which discusses the absence of physical sedimentary structures diagnostic of tidal processes, and documents the evidence that allowed determining the fluvio-dominated character of the deposits (see section 4.4. page 131). The fluvio-dominated character of the Lajas Formation in AC and SVM was first suggested by Canale and Ponce (2012), Ponce et al. (2012), Canale et al., 2013 a, Canale et al., 2013 b, 2015a,b, 2016, 2020) and later recognized in the Picún Leufú Anticline locality by Ponce et al. (2015), Gugliotta et al. (2015a), Canale (2016), Rossi and Steel (2016), Steel et al. (2018). In AC and SVM, the typical tubular tidalite structure (Gingras et al., 2007; Wetzel et al., 2014) is absent, even though gallery systems assigned to Thalassinoides (dominant in proximal prodelta facies) and Ophiomorpha (dominant in distal delta front sections) are abundant. In fact, most of the excavations assigned to Thalassinoides and Ophiomorpha show massive sandy fillings with abundant particulate organic matter and absent to minor mud.

\subsection{Upper section}

15- Pazos et al. (2019) stated, "Progressively, the succession increases the number of beds with wave ripples, some of them with $0.5 \mathrm{~m}$ in wavelength, invariably with coarse grains on top that include siliciclastic granules but also valves as was already shown by Canale et al. (2015a,b) and sometimes with Skolithos. These intervals are quite likely to be caused by local wave-ravinement. The ravinement surface is right below the megaripples, and the megaripples plus coarse grains and bivalves are transgressive lag deposits."

Pazos et al. (2019) omitted to discuss the interpretation proposed for these deposits in section 3.3.1 by Canale et al. (2015). These surfaces have a lateral extension of less than $100 \mathrm{~m}$ and occur at the top of hyperpycnal channel and lobe deposits and at the top of deltaic mouth bars (see Fig. 8B of Canale et al. (2015a,b), and therefore it is unlikely that they constitute transgressive surfaces. These surfaces are interpreted as "washing surface" generated by the action of normal and storm waves on top of hyperpycnal channel and lobe deposits during breaks in sedimentation or at the top of abandoned deltaic mouth bars (Canale et al. 2015a,b, 2016).

16- Pazos et al. (2019) stated, "Interpretation: the section clearly contrasts in sedimentary processes; grain-size, bioturbation and probably in composition with the underlying section taking into account the colour differences (see Zavala, 2002). This interpretation is followed in this paper but contrasts with the suggested delta front-distributary bay interpretation by Canale et al. (2015a,b). Skolithos levels that pass upward to beds with HCS indicate a deepening of the succession not compatible with a shallowing upward stacking pattern observed in deltaic systems."

Pazos et al. (2019) repeatedly asserted the existence of interdistributary bay deposits described by Canale et al. (2015a,b), an affirmation that is false. On the other hand, interpreting the presence of intervals with Skolithos passing upward to hummocky cross-stratified (HCS) beds as evidence of a deepening system is very problematic. One precept of sedimentology and ichnology is that a biogenic or inorganic sedimentary structure does not define an environment, in any case, it is the association of sedimentary structures (facies associations) and trace fossils (ichnofacies) that allow inferring a depositional environment. In fact, Skolithos can be present in a wide variety of marine (shoreface, delta front, offshore, deep marine) and continental (wet interdunes, fluvial levee, lake shoreface) environments (Netto, 2007; Buatois and Mángano, 2011; Knaust, 2017; Knaust and Bromley, 2017), whereas HCS structures have also been recognized in shoreface, offshore, delta front, prodelta, deep marine turbidites and fluvial deposits (Mutti et al., 1999; Arnott and Southard, 1990; Tinterri, 2011). In conclusion, a depositional environment or stacking pattern of a succession cannot be determined from the simple recognition of one sedimentary structure, it is necessary to analyze the set of sedimentary structures (organic and inorganic), the geometry of bodies, and their temporal-spatial disposition.

17- Pazos et al. (2019) indicated, "The uppermost part of the succession, in parts containing intensively bioturbated beds with Skolithos and Rhizocorallium and other strata with channels, documents a shallowing upward trend and a reduction in the accommodation space due to a lateral accretion documented in opposite paleocurrents in the same bed which evidences a meandering pattern. This upper section shows wave dominant action over fluvial processes, but more interestingly the shallowingdeepening and finally shallowing tendency permits to disregards the shallowing upward delta front interpretation as was envisaged by Canale al. (2015a,b)."

As previously mentioned (see comments 13 and 16), it is not possible to discuss the arrangement of a succession based on the presence of two sedimentary structures (Skolithos and HCS). The analysis of a succession should consider the stacking pattern shown by the ichnological and facies associations as done by Zavala and González (2001) and Canale et al. (2015a,b, 2016). 


\section{Ichnology}

\subsection{Tracemaker and behaviour}

18- Pazos et al. (2019 indicated "The track described in this paper is different in substrate in comparison to most of the reported in the literature because it was probably produced on a microbially stabilised substrate (absence of rims), and it is recorded in a sloping surface of a fluvial 3D dune precluding comparison with a horizontal track".

Pazos et al. (2019) suggested that the difference between the footprint in AC and other reports is that it occurred in the stoss-side of the fluvial 3D dune stabilised by microbial activity. Preservation of microbial mats and potential deformational sedimentary structures (in this case an unclear footprint) in the stoss-side of a fluvial dune is highly unlikely, as this type of surface represents an extremely erosive and unstable condition showing the least preservation potential. In addition, Pazos et al. (2019) did not document any macroscopic or microscopic evidence to infer the presence of microbial mats along this surface. As Noffke (2010) suggested, interpreting microbial mats in the rock record requires the analysis of thin sections, since microbial mats present a characteristic lamination generated by alternation of organic and siliciclastic grain laminas, denominated biolaminites (Gerdes et al., 1991, 2000; Noffke, 2010; Carmona et al., 2011; Cuadrado et al., 2011, 2012; Bournod et al., 2014). In addition, biolaminations show specific authigenic minerals (e.g. framboidal pyrite) that indicate specific geochemical conditions within the sediment (Schieber, 1999; Carmona et al., 2011; Cuadrado et al., 2011, 2012; Bournod et al., 2014).

\section{Discussion}

\subsection{Stratigraphy and sedimentology}

19- Pazos et al. (2019) stated "The existence of marginal-marine deposits with occasional subaerial exposure as cropping out in Covunco section needs to be reconsidered in that model".

Contrary to Pazos et al. (2019) and as previously discussed (see answer 6), there is not any single sedimentological and ichnological evidence that support subaerial exposure and marginal marine environments in AC and SVM. The whole interpretation is merely supported by the supposed existence of an unclear single track.

20- Pazos et al. (2019) said "The fluvial dominance suggested by Canale et al. (2015a,b) is clear close to the top of the lower section but the hyperpycnal interpretation is questionable, as not a single deposit shows the attributes of a hyperpycnite, but undisputable tidal modulation is here documented and might be responsible for tidal reworking of such discharges".

Pazos et al. (2019) questioned the hyperpycnal interpretation made in AC and SVM by Canale et al. (2015a,b), indicating that these deposits do not have the attributes of hyperpycnites. However, a comprehensive discussion of the dominant processes in their formation is missing. For example, they did not mention any of the attributes considered by the authors to be diagnostic of a hyperpycnite. Furthermore, they did not discuss the differences between their observations and the evidence documented in section 4.2 "Internal arrangement of hyperpycnal deposits" of Canale et al. (2015a,b). It is also unclear which are the undisputable criteria that Pazos et al. (2019) recognized to determine the tidal character of the deposits. Evidence such as the absence of tubular tidalites in the Ophiomorpha and Thalassinoides infill are completely ignored. Summarizing, a discussion on the topic is hardly possible because they did not explain which criteria they apply to recognize and distinguish hyperpicnites from tidal-influenced deposits.

21- Pazos et al. (2019) stated "Astericiates and cf. Deltapodus ichnofossils are examples of the use of trace fossils in refining paleoenvironmental interpretations".
Once more, the authors erroneously interpreted paleoenvironments based on the observation of two trace fossils, without considering the information provided by the ichnofacies, facies associations and stacking pattern. It is also important to point out that trace fossils represent the organism's response to environmental conditions. Therefore, it is recommended to use the association of certain biogenic structures to interpret certain environmental parameters in order to refine paleoenvironmental interpretations than the mere use of each ichnotaxon separately (Seilacher, 1964a, b, 1967a, b; Bromley, 1996).

To summarize, we can assert that many of the interpretations presented in the contribution of Pazos et al. (2019) are dogmatic and are not supported by clear evidence (e.g. tidal deposits, marginal marine deposits, subaerial exposure). Detailed ichnological and sedimentological studies published in our contributions (Zavala and Gonzalez, 2001; Zavala, 2002; Canale et al., 2013 a; 2015, 2016; Ponce et al., 2012, 2015) provide the evidence to conclude: 1 - the entirely marine character of the successions exposed in AC and SVM, 2- the progradational stacking pattern of the succession, consistent with the organization of facies associations and ichnofacies, 3- the absence of marginal marine environments, and 4- the absence of physical and biogenic sedimentary structures suggestive of subaerial exposure. This evidence is inconsistent with the presence of a dinosaur footprint. Moreover, Pazos et al. (2019) stated that the footprint is preserved in a stoss-side of a 3D fluvial dune, which is an area with extremely poor preservation potential for trace fossils. A track is basically a load cast structure that requires preservation of a soft and at the same time relative plastic substrate. Typically, the local excess of load passively deforms (never erode) the underlying substrate, and should be passively filled by a different lithology having a differential resistance to erosion. Loose sand, like that present at the stoss-side of a 3D dune does not favour track preservation. These erosional features evidence that this doubtful "track" probably corresponds to a tafone related to weathering. Tafonis are very common in Lajas Formation sandstones related to wind erosion, and typically form erosional pockets of different shapes and sizes.

\section{Author statement}

Juan José Ponce: Conceptualization, Investigation, Funding acquisition, Writing, Nerina Canale: Conceptualization, Investigation, Writing, Carlos Zavala: Conceptualization, Investigation, Funding acquisition, Writing.

\section{References}

Arnott, R.W., Southard, J.B., 1990. Exploratory flow-duct experiments on combined-flow bed configurations and some implications for interpreting storm-event stratification. J. Sediment. Petrol. 60, 211-219.

Bhattacharya, J.P., 2006. Deltas. In: In: Posamentier, H.W., Walker, R.G. (Eds.), Facies Models Revisited, vol. 84. Society of Economic Paleontologists and Mineralogists Special Publication, pp. 237-292.

Bournod, C.N., Cuadrado, D.G., Carmona, N.B., Ponce, J.J., Pan, J., 2014. Estructuras sedimentarias inducidas por actividad microbiana (ESIAM) en la planicie de marea de Puerto Rosales, estuario de Bahía Blanca. Rev. Asoc. Geol. Argent. 71, 331-344.

Bromley, R.G., 1996. Trace Fossils. Biology, Taphonomy and Applications. Chapman \& Hall, London, pp. 361p.

Buatois, L., Mángano, M.G., 2011. Ichnology: Organism-Substrate Interactions in Space and Time. Cambridge University Press, pp. 358.

Canale, N., 2016. Análisis icnológico y sedimentológico para la caracterización paleoambiental de las sucesiones hiperpícnicas que integran las formaciones Lajas y Lotena (Jurásico medio), Cuenca Neuquina, Argentina. Tesis Doctoral. Universidad Nacional del Sur, Bahía Blanca, pp. 259.

Canale, N., Ponce, J.J., 2012. Sedimentología de sistemas de lóbulos y canales hiperpícnicos en la Formación Lajas, área de Portada Covunco, Neuquén, Argentina. Resúmenes de la XIII Reunión Argentina de Sedimentología, Salta, Argentina, pp. 48.

Canale, N., Ponce, J.J., Bournod, C.N., Martínez, M.A., Carmona, N.B., 2013 a a. Ondas de sedimento de grano fino generadas por corrientes hiperpícnicas en deltas fluviodominados de la Formación Lajas (Jurásico Medio), Cuenca Neuquina, Argentina. V Simposio Argentino Jurásico. Ameghiniana 50 (4) Suplemento 2013-Resúmenes.

Canale, N., Ponce, J.J., Carmona, N.B., Dritantti, D.I., 2013 b b. Caracterización icnológica de sistemas de barras deltaicas de la Formación Lajas en la Sierra de la Vaca Muerta (Jurásico Medio), Cuenca Neuquina, Argentina. II Simposio Latinoamericano de Icnología. In: Abstracts and Intra-symposium Fieldtrip. Santa 
Rosa, Argentina, pp. 30.

Canale, N., Ponce, J.J., Carmona, N.B., Drittanti, D.I., 2016. Ichnology of deltaic mouthbar systems of the Lajas Formation (middle jurassic) in the Sierra de la Vaca Muerta, Neuquén basin, Argentina. Ameghiniana 53, 170-183.

Canale, N., Ponce, J.J., Carmona, N.B., Drittanti, D.I., Olivera, D.E., Martínez, M.A., Bournod, C.N., 2015a. Sedimentología e icnología de deltas fluvio-dominados afectados por descargas hiperpícnicas de la Formación Lajas (Jurásico Medio), Cuenca Neuquina, Argentina. Andean Geology 114-138.

Canale, N., Ponce, J.J., Carmona, N.B., Drittanti, D.I., Olivera, D.E., Martínez, M.A., Bournod, C.N., 2015b. Sedimentología e icnología de deltas fluvio-dominados afec tados por descargas hiperpícnicas de la Formación Lajas (Jurásico Medio), Cuenca Neuquina, Argentina. Andean Geol. 42, 114-138.

Canale, N., Ponce, J.J., Carmona, N.B., Parada, M.N., Drittanti, D.I., 2020. Sedimentología e icnología de un delta fluvio-dominado, Formación Lajas (Jurásico Medio), cuenca Neuquina, Argentina. Andean Geology 47 (7), 179-206.

Carmona, N., Cuadrado, D., Bournod, C., 2011. Biostabilization of sediments by microbial mats in a temperate siliciclastic tidal flat, Bahia Blanca estuary (Argentina). Sediment. Geol. 237, 95-101.

Cooper, M.R., 2015. On the Iotrigoniidae (Bivalvia: Trigoniida); their palaeobiogeography, evolution and classification. Neues Jahrbuch für Geologie und Paläontologie (277), 49-62.

Cuadrado, D.G., Carmona, N.B., Bournod, C., 2011. Biostabilization of sediments by microbial mats in a temperate siliciclastic tidal flat, Bahia Blanca estuary (Argentina). Sediment. Geol. 237, 95-101.

Cuadrado, D.G., Carmona, N.B., Bournod, C., 2012. Mineral precipitation on modern siliciclastic tidal flats colonized by microbial mats. Sediment. Geol. 271, 58-66.

Dellapé, D.A., Pando, G.A., Uliana, M.A., Musacchio, E.A., 1978. Foraminíferos y ostrácodos del Jurásico en las inmediaciones del arroyo Picún Leufú y la ruta 40 (Provincia del Neuquén, Argentina) con algunas consideraciones sobre la estratigrafía de la Formación Lotena. $7^{\circ}$ Congreso Geológico Argentino, Buenos Aires, pp. 489-507 Actas 2.

Freije, H., Azúa, G., González, R., Ponce, J.J., Zavala, C., 2002. Actividad tectónica sinsedimentaria en el Jurásico del sur de la Cuenca Neuquina. In: V Congreso de Exploración y Desarrollo de Hidrocarburos, Actas: 17. Mar del Plata. Argentina.

Gerdes, G., Klenke, T., Noffke, N., 2000. Microbial signatures in peritidal siliciclastic sediments: a catalogue. Sedimentology 47, 279-308.

Gerdes, G., Krumbein, W.E., Reineck, H.-E., 1991a. Biolaminations-ecological versus depositional dynamics. In: Einsele, G., Ricken, W., Seilacher, A. (Eds.), Cycles and Events in Stratigraphy. Springer-Verlag, Berlin, pp. 592-607.

Gingras, M.K., Lalonde, S.V., Amskold, L., Konhauser, K.O., 2007. Wintering chironomids mine oxygen. Palaios 22, 433-438.

Gugliotta, M., Flint, S.S., Hodgson, D.M., Veiga, G.D., 2015a. Stratigraphic record of riverdominated crevasse subdeltas with tidal influence (Lajas Formation, Argentina). J. Sediment. Res. 85, 265-284.

Gulisano, C.A., Hinterwimmer, G., 1986. Facies deltaicas del Jurásico medio en el oeste del Neuquén. Boletín de Informaciones Petroleras. Tercera Época, Año III (8), 2-31.

Gulisano, C.A., Pando, G.A., 1981. Estratigrafía y facies de los depósitos jurásicos entre Piedra del Aguila y Sañicó, departamento Collón Cura, Provincia del Neuquén. VIII Congreso Geológico Argentino Actas III, pp. 553-557.

Gulisano, C.A., Gutiérrez Pleimling, A.R., Digregorio, R.E., 1984. Esquema estratigráfico de la secuencia jurásica al oeste de la provincia del Neuquén. $9^{\circ}$ Congreso Geológico Argentino, Buenos Aires, pp. 236-259 Actas 1.

Gugliotta, M., Flint, S.S., Hodgson, D.M., Veiga, G.D., 2016a. Recognition criteria, characteristics and implications of the fluvial to marine transition zone in ancient deltaic deposits (Lajas Formation, Argentina). Sedimentology 63, 1971-2001.

Gugliotta, M., Fairman, J.G., Schultz, D.M., Flint, S.S., 2016b. Sedimentological and paleoclimatemodelling evidence for preservation of Jurassic annual cycles in sedimentation, western Gondwana. Earth Interact paper 20-019.

Gugliotta, M., Kurcinka, C.E., Dalrymple, R.W., Flint, S.S., Hodgson, D.M., 2015b. Decoupling seasonal fluctuations in fluvial discharge from the tidal signature in ancient deltaic deposits: an example from the Neuquén Basin, Argentina. J. Geol. Soc. 94-107.

Gulisano, C.A., Gutiérrez Pleimling, A.R., 1995. The Jurassic of Neuquén Basin. Neuquén Province. Field Guide. Secretaría de Minería de la Nación y Asociación Geológica Argentina, Serie E, $\mathrm{N}^{\circ}$ 2. pp. 111 Buenos Aires.

Knaust, D., 2017. Atlas of Trace Fossils in Well Core: Appearance, Taxonomy and Interpretation. Springer, pp. 209.

Knaust, D., Bromley, R.G., 2017. Trace fossils as indicators of sedimentary environments. Dev. Sedimentol. 64 (2012), 960.

Kurcinka, C.E., Dalrymple, R.W., Gugliotta, M., 2018. Facies and architecture of river dominated to tide-influenced mouth bars in the lower Lajas Formation (Jurassic), Argentina. AAPG (Am. Assoc. Pet. Geol.) Bull. 885-912.

Lambert, L.R., 1944. Algunas trigonias del Neuquén. Revista del Museo de La Plata (nueva serie) Paleontología. 2, 357-397.

Leanza, H.A., Garate Zubillaga, J.I., 1987. Faunas de Trigonia (Bivalvia) del Jurásico y Cretácico inferior del Neuquén, Argentina, conservadas en el Museo Juan Olsacher de Zapala. Bioestratigrafía de los Sistemas Regionales del Jurásico y Cretácico de América del Sur 1. Volkheimer, W. (Ed.), Mendoza, pp. 201-255.

Legarreta, L., Gulisano, C., 1989. Análisis estratigráfico secuencial de la Cuenca neuquina (triásico superior-terciario inferior). In: In: Chebli, G.A., Spaletti, L.A. (Eds.), Cuencas sedimentarias argentinas. Serie de Correlación Geológica, vol. 6. pp. 221-243 Tucumán.

Martínez, M.A., Quattrocchio, M.E., 2005. Paleomicroplancton marino del Jurásico medio (formaciones los Molles, Lajas y Lotena) en el centro-oeste de la cuenca Neuquina, Argentina. Evaluación palinoestratigráfica y paleoambiental. Ameghiniana. Suplemento Resúmenes 42, 54R.
Martínez, M.A., Quattrocchio, M.E., Sarjeant, W.A.S., 2001. Análisis palinoestratigráfico de la Formación Lajas, jurásico medio de la Cuenca neuquina, Argentina. Rev. Espanola Micropaleontol. 33, 33-60.

Martínez, M.A., Quattrocchio, M.E., Zavala, C.A., 2002. Análisis palinofacial de la Formación Lajas (Jurásico medio), cuenca neuquina, Argentina. Significado paleoambiental y paleoclimatico. Rev. Espanola Micropaleontol. 34, 81-104.

Martínez, M.A., Olivera, D.E., Zavala, C., Quattrocchio, M.E., 2016. Palynotaphofacies analysis applied to Jurassic marine deposits, Neuquén Basin, Argentina. Facies 62 , $1-16$.

McIlroy, D., 2007. Palaeoenvironmental controls on the ichnology of tide-influenced facies with an example from a macrotidal tide-dominated deltaic depositional system, Lajas Formation, Neuquén Province, Argentina. In: In: Bromley, R. (Ed.), En Sediment-Organism Interactions: a Multifaceted Ichnology, vol. 88. SEPM Special Publication, pp. 195-212.

McIlroy, D., Flint, S., Howell, J.A., Timms, N., 2005. Sedimentology of the jurassic tidedominated Lajas Formation, Neuquén basin, Argentina. In: In: Veiga, G. (Ed.), The Neuquén Basin: a Case Study in Sequence Stratigraphy and Basin Dynamics, vol. 252 Geological Society of London, Special Publication, London, pp. 83-108.

Mutti, E., Tinterri, R., Remacha, E., Mavilla, N., Angella, S., Fava, L., 1999. An introduction to the analysis of ancient turbidite basins from an outcrop perspective. American Association of Petroleum Geologists, vol. 39. Continuing Education Course Note Series, pp. 96.

Naipauer, M., García Morabito, E., Marques, J.C., Tunik, V., Rojas Vera, E., Vujovich, G.I., Pimentel, M.P., Ramos, V.A., 2012. Intraplate Late Jurassic deformation and exhumation in western central Argentina: constraints from surface data and U-Pb detrital zircon ages. Tectonophysics 524-525 (1), 59-75.

Netto, R.G., 2007. Skolithos-dominated piperock in non-marine environments: an example from the Triassic Caturrita Formation, southern Brazil. In: In: Bromley, R.G., Buatois, L.A., Mángano, M.G., Genise, J.F., Melchor, R.N. (Eds.), Sediment-Organism Interactions: A Multifaceted Ichnology, vol. 88. Society for Sedimentary Geology, Special Publication, Tulsa, pp. 109-121.

Noffke, N., 2010. Geobiology: Microbial Mats in Sandy Deposits from the Archaean Era to Today. Springer-Verlag, Berlin, pp. 194.

Pazos, P., González Estebenet, M.C., Cocca, S.E., Pascua, D.V., 2019. The oldest record of a tyreophoran track in Gondwana: geological implications of subaerial exposure in the lower part of the Lajas Formation at the Covunco section (Neuquén Basin), Patagonia, Argentina. J. South Am. Earth Sci. 94, 1-12.

Ponce, J.J., Montagna, A.O., Carmona, N.B., Canale, N., 2015. Guía de Campo. Escuela de Verano 2015. Sedimentología e Icnología de los Sistemas Petroleros no Convencionales de la Cuenca Neuquina (Los Molles-Lajas y Vaca Muerta-Quintuco). Universidad Nacional de Río Negro-Fundación YPF, pp. 112.

Ponce, J.J., Canale, N., Carmona, N.B., Bournod, C.N., Martínez, M.A., Olivera, D.E., 2012. Sedimentología e icnología en sucesiones hiperpícnicas de la Formación Lajas, área de Portada Covunco, Neuquén, Argentina. Resúmenes de la XIII Reunión Argentina de Sedimentología: 175-176. Salta, Argentina.

Quattrocchio, M.E., Sarjeant, W.A.S., 1992. Dinoflagellate cysts and acritarchs from the middle and upper jurassic of the Neuquén basin, Argentina. Rev. Espanola Micropaleontol. 24, 67-118.

Quattrocchio, M., García, V., Martínez, M., Zavala, C., 2001. A Hypothetic Scenario for the Middle Jurasssic, in the Southern Part of the Neuquén Basin. Publicación Especial. Asociación Paleontológica Argentina, Argentina, pp. 1-12.

Riba, O., 1976. Syntectonic unconformities of the alto cardener, Spanish pyrenees: a genetic interpretation. Sediment. Geol. 15, 213-233.

Riccardi, A.C., Damborenea, S.E., Manceñido, M.O., Ballent, S.C., 1988. Hettangiano y Sinemuriano marinos en la Argentina. $5^{\circ}$ Congreso Geológico Chileno, Actas 2 (C), 415-426 Santiago de Chile.

Riccardi, A.C., Gulisano, C.A., 1992. Unidades limitadas por discontinuidades. Su aplicación al Jurásico Andino. Rev. Asoc. Geol. Argent. 45 (3-4), 346-364.

Rossi, V.M., Steel, R.J., 2016. The role of tidal, wave and river currents in the evolution of mixed-energy deltas: example from the Lajas Formation (Argentina). Sedimentology 63, 824-864.

Schieber, J., 1999. Microbial mats in terrigenous clastics: the challenge of identification in the rock record. Palaios 14, 3-12.

Seilacher, A., 1964a. Biogenic sedimentary structures. In: Imbrie, J., Newell, N. (Eds.), Approaches to Paleoecology. John Wiley \& Sons, Chichester, UK, pp. 296-316.

Seilacher, A., 1964b. Sedimentological classiication and nomenclature of trace fossils. Sedimentology $3256-253$.

Seilacher, A., 1967a. Fossil behaviour. Sci. Am. 217, 72-80.

Seilacher, A., 1967b. Bathymetry of trace fossils. Mar. Geol. 5, 413-428.

Steel, E., Simms, A.R., Steel, R., Olariu, C., 2018. Hyperpycnal delivery of sand to the continental shelf: insights from the Jurassic Lajas formation, Neuquén Basin, Argentina. Sedimentology 65, 2149-2170.

Suero, T., 1951. Descripción geológica de la Hoja 36c, Cerro Lotena (Neuquén). Boletín de la Dirección Nacional de Geología y Minería 76, 1-67 Buenos Aires. geological field trips $2012-4(2.1)$.

Tinterri, R., 2011. Combined flow sedimentary structures and the genetic link between sigmoidal and hummocky-crossstratification. Geoacta 10, 43-85.

Volkheimer, W., 1970. Jurassic microfloras and paleoclimates in Argentina. In: Proceedings and Papers: Second Gondwana Symposium, pp. 543-549 Pretoria.

Volkheimer, W., 1978. Microfloras fósiles. In: Geología y recursos Naturales del Neuquén, Relatorio del $7^{\circ}$ Congreso Geológico Argentino, pp. 147-161 Buenos Aires.

Wetzel, A., Carmona, N., Ponce, J.J., 2014. Tidal signature recorded in burrow fill. Sedimentology 61, 1198-1240.

Zavala, C.A., 1993. Estratigrafía y análisis de facies de la Formación Lajas (Jurásico medio) en el sector suroccidental de la Cuenca Neuquina, provincia del Neuquén. República Argentina. Tesis Doctoral. Universidad Nacional del Sur, Bahía Blanca, pp. 
254.

Zavala, C., 1996. Sequence stratigraphy in continental to marine transitions. An example from the middle jurassic Cuyo Group, south Neuquén basin, Argentina. GeoResearch forum. Advances in Jurassic Research, vols. 1-2. Transtec Publications, Switzerland, pp. 285-294 1996.

Zavala, C., 1996. High-resolution sequence stratigraphy in the middle jurassic Cuyo Group, south Neuquén basin, Argentina. GeoResearch forum. Adv. Jurassic Res. s. 1-2 (1996), 295-304 Transtec Publications, Switzerland.

Zavala, C.A., 2002. El contacto entre los Grupos Cuyo y Lotena (Jurásico) en la Sierra de la Vaca Muerta. Cuenca Neuquina, Argentina. In: In: Cabaleri, N. (Ed.), XV Congreso Geológico Argentino, El Calafate, Actas, vol. 1. pp. 711-715.

Zavala, C., González, R., 2001. Estratigrafía del Grupo Cuyo (Jurásico inferior-medio) en la Sierra de la Vaca Muerta, Cuenca Neuquina. Boletín de Informaciones Petroleras. Tercera Época $17^{\circ}$ 65, 40-54.

Zavala, C.A., Freije, H., 2002. Cuñas clásticas jurásicas vinculadas a la Dorsal de Huincul. Un ejemplo del área de Picún Leufú. Cuenca Neuquina, Argentina. In: V Congreso de Exploración y Desarrollo de Hidrocarburos, pp. 14 Mar del Plata, Argentina. 